\title{
The Effect of Fraud Pentagon on Fraudulent Financial Statement of Banking in Indonesia
}

\author{
Mega Arisia Dewi \\ Sekolah Tinggi IImu Ekonomi Indonesia, Surabaya, Indonesia \\ megaarisiadewi@stiesia.ac.id
}

\begin{abstract}
This study aims to determine the effect of financial targets, financial stability, external pressure, effective monitoring, nature of industry, change in auditors, rationalization, change of company directors, CEO's Picture on fraudulent banking financial statements in Indonesia for 2014-2019. This study uses the dependent variable, namely fraudulent financial reporting, while the independent variables are financial targets, financial stability, external pressure, effective monitoring, nature of industry, change in auditors, rationalization, competence and arrogance. The show that the variable financial targets, change in auditors, change of directors and CEO's picture have no effect on the detection of fraudulent financial statements. Meanwhile, financial stability, external pressure, ineffective monitoring, nature of industry, and rationalization have an effect on the detection of fraud in financial reports for 2014-2019. The results of this study provide an understanding for the public and the general public that the government's efforts so far have always played a major role in maintaining the condition of the Indonesian economy in order to avoid attempts to cheat financial statements.
\end{abstract}

Keywords: fraud pentagon, fraudulent financial reporting, banking

\begin{abstract}
Abstrak
Penelitian ini bertujuan untuk mengetahui pengaruh financial target, financial stability, external pressure, ineffective monitoring, nature of industry, change in auditor, rationalization, pergantian direksi perusahaan, CEO's Picture terhadap kecurangan laporan keuangan perbankan di Indonesia Tahun 2014-2019. Penelitian ini menggunakan variabel dependen yaitu fraudulent financial reporting sedangkan variabel independennya, yaitu financial target, financial stability, external pressure, ineffective monitoring, nature of industry, change in auditor, rationalization, competence dan arrogance. Hasil penelitian menunjukkan bahwa variabel financial target, change in auditor, pergantian direksi dan CEO's picture tidak berpengaruh terhadap deteksi kecurangan laporan keuangan. Sedangkan financial stability, external pressure, ineffective monitoring, nature of industry, dan rationalization berpengaruh terhadap deteksi kecurangan laporan keuangan tahun 2014-2019. Hasil penelitian ini memberikan pemahaman bagi masyarakat dan khalayak umum bahwa upaya pemerintah selama ini selalu berperan banyak untuk menjaga kondisi perekonomian Indonesia agar terhindar dari upaya tindkan kecurangan laporan keuangan.
\end{abstract}

Kata kunci: fraud pentagon, pelaporan keuangan palsu, perbankan

\section{Cara Mengutip:}

Dewi, M.A. (2021) The Effect of Fraud Pentagon on Fraudulent Financial Statement of Banking in Indonesia. Esensi: Jurnal Bisnis dan Manajemen, Vol 11(2), 189-206. https://doi.org/10.15408/ess.v11i2.23031. 


\section{INTRODUCTION}

The financial report is a structural presentation issued by the company based on the results of company performance (Yuliani, 2010). Financial reports are prepared to provide information and show the financial condition of a company which will later be used to determine economic decisions by users of financial statements, for example, stakeholders (Yuliani, 2010). Financial reports that have high integrity and can be said to be accurate when they can be presented truthfully, honestly and relevant. However, the fact that the company sometimes shows the results of the company's performance is in a state that is not true or does manipulation or misstatement intentionally carried out by the company's management. This is because the company wants to get a good spotlight from other parties. This is what drives the manipulation of information in financial reports. In addition, this action usually arises because of differences in interests or inequality of information between the agent and the principal.

Today, in the business world, all companies are competing to advance the company each of them, it is not surprising that the practice of cheating is one of their efforts to develop their business (Jaya \& Narsa, 2021). So, this fraudulent practice is no longer commonplace for business people and has become an open secret to the public. Not only in companies, even this fraudulent practice is very well known and often occurs in the government sector. Various parties have been harmed by this action because the information they received was not really accurate and relevant. This is also even more disadvantageous for the investors because they have made the wrong decision to invest their capital in these companies that commit fraudulent practices, resulting in failure to get returns from their investment activities (Jaya \& Narsa, 2020).

Fraudulent actions in financial reports are currently increasing, with the impact not only on individual investors, but also on global economic stability. Fraud is an action or act that is done deliberately, consciously and there is a desire to abuse everything that belongs together, for example company or state resources for personal enjoyment and then presenting false information to cover up the abuse (Mardianto \& Tiono, 2019). Fraud in financial statements can occur intentionally by eliminating material facts, or accounting data that can be misleading and when used as material for consideration with all existing information, so that it will cause users of financial statements to change or exchange their judgments or decisions (Ozcelik, 2020). In practice, fraud in financial statements consists of manipulation of financial records, intentionally to eliminate events, transactions, accounts or other significant information or misapplication of accounting principles, policies or procedures used to measure, record, report and disclose transactions.

Fraudulent financial reporting over time has actually increased, this cannot be underestimated by all parties (Bawekes et al., 2018). The number of cases of economic crimes that occur in the business world requires auditors to know what factors can detect fraud in companies. With the development of the times, the science of fraud can also be seen from previous studies that provide an overview of fraudulent financial reporting practices. Some of the aforementioned phenomena are evidence that fraud in profits is still common (Jaya \& Narsa, 2020). According to Chandra et al. (2021), management can use policies in financial statements to reduce and increase profits according to their interests by not violating accounting principles. 
The theory of fraud is growing. Many studies have been conducted to look at the factors driving fraud. Cahyani et al. (2021) found the fraud pentagon model which states that the elements in the fraud pentagon consist of arrogance, competence or capability, pressure, opportunity, and rationalization. This pentagon fraud looks more at a broader fraud scheme and involves manipulation by the CEO. The latest model of cheating theory "Fraud Pentagon Theory" proposed by Crowe, is a refinement of Creesey's theory "Fraud Triangle Theory" and Wolfe's "Fraud Diamond Theory" (Septriani, 2018). Pressure (pressure) faced by management to improve company performance or not be able to achieve goals, can have an impact on fraud. Especially if there is an opportunity to commit fraud, such as a weak internal control system and a small risk of detection. In dealing with this situation, management considers that it is a rationalization to carry out financial manipulation. Pressure and rationalization encourage management to commit fraud, while opportunities become an entry point for fraud.

Dewi \& Kurniawan (2017) states that at least 70\% of fraud is committed by perpetrators by combining pressure with arrogance and greed. Arrogance is an attitude of superiority and greed that needs to be directed and corrected. However, the results of research conducted by Sarikhani \& Ebrahimi (2021) and Manurung \& Hardika (2015) stated that there was no significant impact of arrogance on fraud in the report. finance. By referring to research conducted by previous researchers, there are differences between this study and this study. The difference between this researcher and the previous one is that the object of this research is observing the government banking company sector. This sector is considered the riskiest sector in Indonesia. Thus, the purpose of this study is to test the Pentagon's Fraud Theory of Fraud in the Financial Statements of State-Owned Banking Companies in Indonesia for 2014-2019.

The definition of fraud according to IAI (2012) explains the definition of fraud is any accounting act as: (1) Misstatement arising from fraud in financial reporting, namely misstatement or deliberate omission of amounts or disclosures in financial statements to deceive users of financial statements, (2) Misstatement arising from improper treatment of assets (often referred to as misuse or embezzlement) related to the theft of an entity's assets which results in the financial statements not being presented in accordance with generally accepted accounting principles in Indonesia. Some definitions of fraud according to experts, it can be concluded that fraud is an act of an individual or organization intentionally to cheat, hide, or gain profit in a condition, where such action can harm the parties concerned Likewise, fraud in financial reports can make the information presented in the financial statements not show its original condition, so that information can make users of financial statements make wrong decisions and experience large losses.

The fraud diamond is an extension of Cressey's fraud model. The elements contained in the fraud diamond are incentive/pressure, opportunity, rationalization and capability. Wolfe and Hermanson argue that there is a fraud triangle renewal to improve the ability to detect and prevent fraud by adding a fourth element, namely capability.

Omukaga (2021) describe the characteristics related to capability elements that are very important in the person of the fraudster, namely: 1) Positioning. A person's position or function in an organization can provide the ability to create or take advantage of opportunities 
for fraud. A person in a position of authority has more influence over a particular situation or environment; 2) Intelligence and creativity. These fraudsters have sufficient understanding and exploiting weaknesses of internal control and to use authorized positions, functions or access to the greatest advantage; 3) Confidence/ego. The individual must have a strong ego and great confidence that he will not be detected. The general personality type includes someone who is encouraged to succeed at all costs, is selfish, self-confident, and often loves himself (narcissism). According to the Diagnostic and Statistical Manual of Mental Disorder, narcissism personality disorder includes a need to be admired and a lack of empathy for others. Individuals with this disorder believe that they are superior and tend to want to demonstrate their accomplishments and abilities; 4) Coercion. The fraudster can force others to commit or hide the fraud. An individual with a persuasive personality can be more successful in convincing others to go along with the scam or look the other way; 5) Deceit. Successful deception requires effective and consistent deception. To avoid detection, the individual must be able to lie convincingly, and must trace the story as a whole; and 6) Stress. Individuals need to be able to control stress because cheating and keeping it hidden can be very stressful.

The fraud pentagon theory is the latest theory on fraud put forward by Crowe Howart in 2011. The theory that develops from the fraud triangle theory previously put forward by Creesey, in this theory adds two other elements of fraud, namely competence and arrogance. Competence in the fraud pentagon theory has a similar meaning to the capability previously described in the fraud diamond theory by Skousen et al. (2009). Competence is the ability of employees to penetrate internal control within their company, develop sophisticated embezzlement strategies, and be able to control social situations that are able to benefit them by influencing others to work with them (Skousen et al., 2009). According to Vrontis et al. (2020), arrogance is a lack of conscience which has superiority or the arrogant nature of a person who has high self-confidence so that they believe that internal control does not apply to him (personal). Meanwhile, according to Jaya \& Poerwono (2020) this arrogance arises from the belief that he is capable of cheating and the existing controls cannot befall him so that the perpetrator of fraud usually thinks freely to commit fraud without fear of sanctions that ensnare him.

Fraud is an action that is very detrimental to a company. In accordance with Law No. 31 of 1999 junto Law no. 20 of 2001 states that fraudulent acts and actions that harm state finances are types of corruption. So that fraud like this can be categorized as a criminal act of corruption. According to Effendi, there are 3 causes of fraudulent financial reporting, namely: manipulation, falsification, alteration of financial report notes and supporting documents for the presented financial statements; misrepresentation or significant misinformation in the financial statements; and misapplication of accounting principles relating to the amount, classification, presentation and disclosure.

According to Ahmed \& Duellman (2007), several motivations that encourage management to do earning management include the following: 1) Bonus purposes, managers who have information on the company's net income will act opportunistically to manage earnings by maximizing current earnings; 2) Political motivation, earnings management is used to reduce reported earnings in public companies. Companies tend to reduce their reported profits due 
to public pressure which results in the government setting tougher regulations; 3) Taxation motivations, the motivation for tax savings, are the most obvious earnings management motivations. Various accounting methods are used with the aim of saving income tax; 4) CEO turnover, CEOs who are approaching retirement will tend to increase their income to increase their bonuses. And if the company is performing poorly, they will maximize revenue so as not to be laid off; 5) Initial Public Offering (IPO), companies that are going to go public do not yet have market value, and cause managers of companies that are going to go public to manage earnings in their prospectuses in the hope of increasing the company's stock price; 6) The importance of providing information to investors, information about the company's performance must be conveyed to investors so that earnings reporting needs to be presented so that investors continue to judge that the company is in good standing.

Earning management measures are the basis for fraudulent financial reporting. Jaya \& Poerwono (2019) said that earnings management actions have led to several widely known cases of accounting reporting scandals, including Enron, World Com, and the majority of other companies in the United States. Likewise in Indonesia, there have been several cases involving PT. Ades and PT Kimia Farma Tbk, which originated from the detection of financial report manipulation.

Financial targets in the form of return on business that the company wants to achieve are often called financial targets. One of the measurements to assess the level of profit obtained by the company for the business it has spent is ROA (Return on Asset). Return On Asset is used to measure company management in obtaining profit (profit) as a whole. The greater the ROA obtained, the greater the level of profit achieved by the company and the better the position of the company in terms of asset use (Sihombing, 2014).

Chandra et al. (2021), Jaya \& Poerwono (2019) also prove that companies that have large profits (measured by profitability or ROA) are more likely to do earnings management than companies that have low profits. This is also supported by research by Sihombing (2014), Sumiati (2020), Rahmayuni (2018), Rexhepi et al. (2013), Septriani \& Handayan (2018), Afiah \& Aulia (2020) state that financial targets are influential in detecting fraudulent financial statements.

According to SAS No. 99, managers face pressure to commit fraud and manipulation of financial statements when the financial stability and profitability of their companies are threatened by economic, industrial and other situations. Skousen et al. (2009) indicate companies that are experiencing growth below the industry average, allowing management to manipulate financial statements to improve the company's prospects. Research conducted by Sihombing (2014); Septriani and Handayani (2018); Jaya \& \& Poerwono (2019), Rahmayuni (2018) shows that financial stability, which is proxied by changes in total assets (ACHANGE), is proven to have an effect on financial statement fraud.

Companies often experience pressure from external parties. One of the pressures that company management often experiences is the need to obtain additional debt or external sources of financing in order to remain competitive, including research financing and development or capital expenditures (Skousen et al., 2009). Managers will feel under pressure when they have to meet the need to obtain additional finance through debt and investment financing (Tessa, 2016). The need for external financing is related to cash generated 
from debt which in this study is proxied by the leverage ratio (Agustina \& Pratomo, 2019; Septriani and Handayani, 2018; Pitaloka and Majidah, 2019).

Ineffective monitoring is a condition where there is no effectiveness of the company's internal control system. This can occur because of the dominance of management by one person or small group, without compensation control, ineffective supervision of the board of directors and audit committee over the financial reporting process and internal control or the like (SAS No. 99) (Septriani \& Handayani, 2018). Lack of control from the company's internal parties is an opportunity for some parties to manipulate data in financial reports (Tessa, 2016). One of the ways to minimize fraud is by means of a good supervisory mechanism within the company (Septriani \& Handayani, 2018; Mardianto \& Tiono, 2019; Agustina \& Pratomo, 2019; Pitaloka \& Majidah, 2019).

Nature of industry is an ideal condition for a company or organization in industry. One form of the nature of the industry is the condition of the company's receivables, where companies that are considered to have ideal conditions are companies that have less receivables. Skousen et al. (2009) argue that a good company will reduce and reduce the amount of company receivables and increase the company's cash flow receipts. The high value of receivables against sales in a company indicates that accounts receivable are assets that have a higher risk of manipulation. Because, if a company has a high ratio of accounts receivable to sales, then this makes it possible for management to manipulate financial statements so that these receivables look smaller. Thus, in this study, the nature of industry is proxied by the change in the ratio of accounts receivable to sales. Research by Sihombing (2014), Indriani (2017), Septriani \& Handayani, (2018), and Rahmayuni (2018) stated that the nature of industry has a positive effect on fraudulent financial statements.

Change in auditors or changes in auditors used by companies can be considered as a form of eliminating the fraud trail found by previous auditors (Septriani, 2018). A study conducted by Sihombing (2014) shows that changes in auditors can occur due to valid reasons, the risk of subsequent audit failure and litigation will be higher than in subsequent years. Jaya \& Poerwono (2019), Septriani \& Handayani (2018), Rahmayuni (2018), Mardianto \& Tiono (2019) argue that auditor changes do not have a significant relationship to financial statement fraud.

According to Skousen et al. (2009) states that rationalization has a subjective assessment of the company, subjective judgment and decision making are reflected in the company's accrual value. The accrual value is not a real value, so management can play accruals in the company to get the value it expects, so that the accrual can be used as an excuse by management to justify its manipulation (Septriani, 2018; Jaya \& Poerwono, 2019). So, in this study will use the proxy Total Accrual to Total Assets (TATA) as a proxy for rationalization, where Total Accrual to Total Assets is the ratio of total accruals in a company to total assets. Research by Sihombing (2014) and Septriani \& Handayani (2018) provide evidence that rationalization proxied by TATA affects financial statement fraud.

According to Tessa \& Harto (2016), change of directors is chosen as a variable from one of the elements in Crowe's fraud pentagon theory, competence. The change of directors is indicated as being able to illustrate the ability to perform stress management. Jaya \& Poerwono (2019) argue that fraud will not occur without the right people with the right 
abilities to carry out every detail of the fraud. Competence, which means a person's ability to commit fraud in order to achieve certain goals. Changing the board of directors can be a company effort to improve the performance of the previous directors (Jaya \& Narsa, 2020). By making changes to the composition of the board of directors or by recruiting new directors who are considered more competent in their fields, the change of directors also indicates a certain political interest to replace the previous board of directors. According to Sihombing \& Rahardjo (2014); Annisya et al. (2016), Yesiariani \& Rahayu (2016), Pangesty et al. (2018) directors who have good competence and are loyal to the company are unlikely to commit fraud. So that the higher the ability of the directors will not affect the existence of fraudulent financial statements.

CEO's picture is a photo of the CEO emblazoned on the company's annual report. The CEO's photo emblazoned in a company's annual report can represent the level of arrogance or superiority the CEO possesses. A CEO tends to be more willing to show everyone the status and position he has in the company because they don't want to lose that status or position (or feel they are not considered), this is consistent with one of the elements described by Crowe (2011). A high level of arrogance can lead to fraud because the arrogance and superiority of a CEO makes the CEO feel that any internal control will not apply to him because of his status and position. According to Husmawati et al., (2017), Apriliana \& Agustina (2017), Jaya \& Poerwono (2019), Jaya \& Narsa (2020); Septriani and Handayani (2018); there is also the possibility that the CEO will do whatever it takes to maintain his current position and position.

\section{METHODS}

This research is descriptive quantitative research, namely research that seeks to explain the variables by collecting data that will be processed to see the effect of these variables. This research is also explanatory research, to get clarity of phenomena that occur in the empirical world (real world) and to try to get answers (verificative), which aims to explain the causality relationship between variables through data analysis in the context of testing hypotheses. The population in this research are all banking companies in Indonesia that are listed on the Indonesia Stock Exchange. The companies used as samples in this study are banking companies listed on the Indonesia Stock Exchange. The research period was conducted for 5 years during 2014-2019. The data to be used is more focused on secondary data, in the form of archival methods and annual financial reports of banking companies in Indonesia. The sampling technique used in this study was purposive sampling. Purposive sampling technique is a sampling technique with certain criteria). The sample criteria used in this study are that the sample can provide the information needed, including: 1) Go public banking companies listed on the Indonesia Stock Exchange from 2014-2019 and 2) Banking companies that publish annual financial reports (audits) as of December 31, 2014-2019 in a timely manner.

Earning management is used as a proxy for fraudulent financial statements in this study using the Discretionary Accruals Value of the Modified Jones Model. Discretionary accruals are a component of accruals derived from the manager's earning management. Meanwhile, non-discretionary accruals are a component of accruals that occur along with 
changes in company activities (Jaya \& Narsa, 2020). Discretionary accruals (DACC) are obtained by setting aside total accruals (TACC) and nondiscretionary accruals (NDACC). The calculation model is as follows:

$$
\text { TACit }=\text { Niit }- \text { CFOit }
$$

Where:

TACit = Total Accruals of company i-year $\mathrm{t}$

Niit $=$ Net income of company i-year $\mathrm{t}$

CFOit = Operation Cash Flow of company i-year $\mathrm{t}$

The total accruals value (TAC) is estimated by the OLS regression equation as follows:

$$
\frac{\text { TACit }}{\text { Ait }-1}=\beta 1\left(\frac{1}{\text { Ait }-1}\right)+\beta 2\left(\frac{\Delta \text { Revt }}{\text { Ait }-1}\right)+\beta 3\left(\frac{P P E t}{\text { Ait }-1}\right)+\varepsilon
$$

By using the regression coefficient above, the value of nondiscretionary accruals (NDACC) can be calculated by the formula:

$$
\text { NDACCit }=\beta 1\left(\frac{1}{\text { Ait }-1}\right)+\beta 2\left(\frac{\Delta \text { Revt }}{\text { Ait }-1}-\frac{\Delta \text { Rect }}{\text { Ait }-1}\right)+\beta 3\left(\frac{\text { PPEt }}{\text { Ait }-1}\right)+\varepsilon
$$

Furthermore, discretionary accruals (DACC) are calculated as follows:

$$
\text { DACCit }=\frac{\text { TACit }}{\text { Ait }}-\text { NDACCit }
$$

Where:

DACCit $=$ Discretionary accruals of company $\mathrm{i}$ in year $\mathrm{t}$

NDACCit $=$ Nondiscretionary accruals of company $i$ in year $t$

TACit = Total accruals of company $\mathrm{i}$ in year $\mathrm{t}$

Niit $\quad=$ Net income of company $\mathrm{i}$ in year $\mathrm{t}$

CFOit $=$ Operation Cash Flow of company $\mathrm{i}$ in year $\mathrm{t}$

Ait $\quad=$ Total assets of company $\mathrm{i}$ in year $\mathrm{t}$

$\Delta$ revt $=$ Change in company i's income in year $\mathrm{t}$

PPEt $=$ Fixed assets of the company in period $\mathrm{t}$

$\Delta$ rect $=$ Change in receivables of company $\mathrm{i}$ in year $\mathrm{t}$

$\mathrm{E} \quad=$ error

Financial stability is a state of stability that describes a company's financial condition. Financial stability is proxied by ACHANGE, which is the ratio of changes in assets for two years. This formula is also used by Tessa (2016) in her research. ACHANGE is calculated by the formula: (Total asset $t_{t}$ Total asset $\left.{ }_{(\mathrm{t}-1)}\right) /$ Total asset $_{(\mathrm{t}-1)}$

External Pressure is excessive pressure for management to meet the requirements or expectations of third parties. External pressure in this study is proxied by the Leverage ratio (LEV). This formula is also used in Bawekes (2018); and Tessa (2016). Leverage ratio is calculated by the formula: Liability/Total asset

Ineffective monitoring is a situation where the company does not have an effective internal control system in monitoring company performance. This study proxies effective 
monitoring of the ratio of the number of independent boards of commissioners (BDOUT). This formula is also used by Bawekes (2018) in his research: (Amount of independent commissioner board/Total of commissioner board).

Nature of Industry is an ideal state for a company in the industry. The condition of accounts receivable is a form of the nature of the industry that can be responded to by different reactions from each company manager. A good company will try to reduce the amount of receivables and increase the company's cash receipts. This study uses the ratio of Total Receivables as a proxy for the Nature of Industry. In research Sihombing (2014) also uses the same formula: ((Receivable $t /$ Sales $\mathrm{)}$ - $\left(\right.$ Receivable $_{\mathrm{t}-\mathrm{1}} /$ Sales $\left._{\mathrm{t}-1}\right)$ ).

Change in auditors or changes in auditors used by the company can be considered as a form of eliminating the fraud trail that was found by the previous auditor. This tendency encourages companies to change their independent auditors in order to cover up fraud in the company. Therefore, rationalization is proxied in this study by the change of independent auditors $(\triangle \mathrm{CPA})$ which is measured using dummy variables.

Rationalization is laden with subjective assessments of the company. The subjective assessment and decision making of the company will be reflected in the accrual value of the company (Skousen et al., 2009). Total accruals will affect financial statement fraud because these accruals are strongly influenced by management decision making in the rationalization of financial statements (Beneish, 1999). Therefore, rationalization will be proxied by the ratio of Total Accruals (TATA).

Competence or expertise possessed by a person in the company will affect how that person commits fraud. Wolfe and Hermanson (2004) argue that changes in the board of directors can cause a stress period that has an impact on opening up opportunities for fraud. Therefore, this study proxy's competence with a change of directors (DCHANGE) as measured by a dummy variable where if there is a change of directors in the financial statements, it is coded 1 and if there is no change of directors in the financial statements, it is coded 0 .

Tesssa and Harto (2016) examined that one measure of arrogance can be seen from the number of CEO images displayed in the company's annual report. The number of CEO images displayed in a company's annual report can represent the level of arrogance and superiority that the CEO has. However, this study proxy's arrogance with the CEO's image in the company's annual report, measured using a dummy variable, where if there is a photo of the CEO on the financial report, code 1 is given and if there is no CEO's photo on the financial report on the financial report, code 0 is given.

The analysis technique used in this research is multiple linear regression analysis. Researchers used a test tool, namely IBM SPSS statistics to test the relationship between the independent variables and the dependent variable. In this analysis test using a model form, as follows:

DACCit=ß0+ß1ROA+ß2ACHANGE+ß3LEV+ß4BDOUT+ß5RECEIVABLE+ß6ACPA+ß7TATA+ B8DCHANGE+ $\varepsilon$ 
Where:

ß0

$ß 1, ß 2, ß 3, ß 4, ß 5, ß 6, ß 7, ß 8, ß 9$

DACCit

ROA

ACHANGE

LEV

BDOUT

RECEIVABLE

$\triangle \mathrm{CPA}$

TATA

DCHANGE

e
$=$ Constant regression coefficient

$=$ Regression coefficients of each proxy

$=$ Discretionary accruals change $\mathrm{i}$ in year $\mathrm{t}$

= Return on Assets

$=$ The ratio of changes in total assets

$=$ The ratio of total liabilities to total assets

$=$ The ratio of the independent board of commissioners

$=$ The ratio of changes in accounts receivable

$=$ Change of independent auditors

$=$ The ratio of total accruals to total assets

$=$ Change of Directors

$=$ Error term

\section{RESULT AND DISCUSSION}

\section{Result}

The financial target variable is measured using ROA, where from a total of 180 company data shows an average ROA value of 2.495. This shows that the effectiveness of the company during the Covid 19 period to generate net income reached 2.495 of the total assets owned by the company. The smallest ROA value is 0.9986 . Meanwhile, the highest ROA value was obtained 3,9885. The standard deviation of ROA which shows the number 0.782 indicates that the number is smaller than the average number. This illustrates that the data is evenly distributed. The financial stability variable is measured using the ratio of changes in total assets for two years. The average asset change ratio (ACHANGE) from company data shows the figure of 1.691 . This means that changes in the company's assets have an increase of $16.9 \%$ of the company's total assets each year. The lowest value of the change in total assets ratio shows a value of 0.191 during 2014-2019. Meanwhile, the highest asset change ratio value shows a value of 2.983 during the Covid 19 period. The standard deviation shows the number 0.721 is smaller than the average value, which means that the data is evenly distributed.

External pressure variable as measured by the company's leverage ratio has an average of 7,934. This shows that the sample companies in this study have a liability smaller than the total assets of the company on average. The smallest leverage value is 0.414 , while the largest leverage value is 16.992. The standard deviation of leverage is 5.064. The standard deviation value is smaller than the average value, which means that the data is spread evenly. The effective monitoring variable is measured using the ratio of the independent board of commissioners (BDOUT). The ratio of the independent board of commissioners of the sample companies has an average value of 0.468 . This means that the average sample company has an independent board of commissioners of $46.8 \%$ of the total board of commissioners in their company. The ratio of the lowest board of commissioners was 5.319 and the ratio of the highest independent board of commissioners was 5.667. The standard deviation is 2,768 (smaller than the average), meaning that the data is spread evenly. 
Table 1. Descriptive Statistics Test Results

\begin{tabular}{lccccc}
\hline & N & Minimum & Maximum & Mean & Std. Deviation \\
\hline ROA & 180 &, 9986 & 3,9885 & 2,495848 &, 7821812 \\
ACHANGE & 180 &, 1914 & 2,9833 & 1,691899 &, 7210439 \\
LEVERAGE & 180 &, 4149 & 16,9923 & 7,934738 & 5,0642783 \\
BDOUT & 180 & 5,3198 & 5,6667 &, 468247 & 2,7681572 \\
RECEIVABLE & 180 &, 0056 & 41,9905 & 16,257846 & 13,7956568 \\
CHANGE IN AUDITOR & 180 & 0 & 1 &, 06 &, 230 \\
TATA & 180 &, 0969 & 1,9569 & 1,180733 &, 6948200 \\
COMPETENCE & 180 & 0 & 1 &, 56 &, 498 \\
CEO'S PICTURE & 180 & 0 & 1 &, 84 &, 363 \\
DACC & 180 &,- 7636 & 2,7933 & 1,358655 &, 8319840 \\
Valid N (listwise) & 180 & & & & \\
\hline
\end{tabular}

Nature of industry which is measured using the ratio of changes in company accounts receivable (RECEIVABLE) has an average of 16.257. This means that the average accounts receivable of the sample companies experienced a change of 16.257 from changes in company sales. The smallest ratio value is 0.0056 , which means that the sample companies experienced a decline in accounts receivable by $5.6 \%$ of the change in sales during 2014-2019. The largest ratio value was obtained at 41.99 , which means that the company experienced an increase in accounts receivable by $41.9 \%$. The standard deviation is 13.795 , which indicates the value is smaller than the average. This means that the research data is evenly distributed. Change in auditors or auditor changes have an average value of 0.06 . This shows that of the total sample companies, the frequency of occurrence of external auditor turnover is $6.1 \%$ with a standard deviation of 0.230 . The lowest value is 0 and the highest value is 1 where in measuring this variable the writer uses a dummy variable.

Rationalization which is measured using the ratio of Total Accrual to Total Assets (TATA) has an average value of 1.180. This shows that the total accruals of the sample companies are smaller than the total assets owned by the company. The lowest TATA value shows a value of 0.096 while the highest TATA value shows a value of 1.956 during 20142019. The TATA standard deviation shows the number 0.694 (smaller than the average), meaning that the data obtained has been spread evenly. The change of directors' variable is proxied by competence (COMPETENCE) having the lowest value of 0 and the highest value of 1 (using a dummy variable). The average turnover of directors shows a value of 0.56 , which means that the turnover of directors from the company data collected is $56 \%$ with a fairly large standard deviation of 0.498 . The variable of directors' turnover is proxied by arrogance having the lowest value of 0 and the highest value of 1 (using a dummy variable). The average CEO's picture shows a value of 0.84 , which means that the majority of the company's annual reports contain CEO photos of $84 \%$ with a standard deviation of 0.363 . 
Table 2. Normality Test Results

\begin{tabular}{llc}
\hline & & Unstandardized Residual \\
\hline $\mathrm{N}$ & Mean & 180 \\
Normal Parameters & OE- -7 &, 14245812 \\
& Std. Deviation &, 132 \\
Most Extreme Differences & Absolute &, 132 \\
& Positive &,- 116 \\
Kolmogorov-Smirnov $\mathrm{Z}$ & Negative & 1,774 \\
Asymp. Sig. (2-tailed) & &, 369 \\
\hline a. Test distribution is Normal. & & \\
b. Calculated from data. & &
\end{tabular}

The dependent variable of this research is discretionary accrual (DACC) which is calculated based on the Modified Model Jones. Based on the table above, the DACC has an average of 1.358. This means that the average company that conducts discretionary accruals annually is 1.358 of the total accruals in each financial report published during 2014-2019. This data shows that the average accruals discretionary in the company's financial statements is still low. The standard deviation shows the number 0.831 , where this number is smaller than the average value, which means that the data distribution is evenly distributed.

From Table 2, it can be seen the significance value or Asymp. Sig. (2-tailed) of 0.369 which indicates that the significant value is $>0.05$. Thus, the residual value of all research variables has been normally distributed, thus indicating that this study has met the criteria for normality test.

Based on Table 3, it can be seen that the multicollinearity test results show a tolerance value above 0.1 and a Variance Inflation Factor (VIF) value below 10 for each variable. The multicollinearity test results, it can be concluded that all the independent variables in this regression model have no correlation between one variable and another.

Table 3. Multicollinearity Test Results

\begin{tabular}{lccccc}
\hline \multirow{2}{*}{ Model } & \multicolumn{2}{c}{ Unstandardized Coefficients } & Standardized Coefficients & \multicolumn{2}{c}{ Collinearity Statistics } \\
\cline { 2 - 6 } & B & Std. Error & Beta & Tolerance & VIF \\
\hline (Constant) &, 137 &, 060 & &, 006 &, 374 \\
ROA &, 006 &, 023 &, 097 &, 528 & 1,892 \\
ACHANGE &, 112 &, 021 &, 063 &, 233 & 4,295 \\
LEVERAGE &, 010 &, 004 &, 061 &, 247 & 4,056 \\
BDOUT &, 018 &, 008 &, 832 &, 157 & 6,376 \\
RECEIVABLE &, 050 &, 002 &, 023 &, 691 & 1,448 \\
CHANGE IN AUDITOR &, 085 &, 057 &, 100 &, 141 & 7,086 \\
TATA &, 120 &, 042 &, 002 &, 950 & 1,052 \\
COMPETENCE &, 003 &, 023 &,- 020 &, 985 & 1,015 \\
CEO'S PICTURE &,- 046 &, 030 & & & \\
a. Dependent Variable: DACC & & & & & \\
\hline
\end{tabular}


This test is conducted to determine the feasibility of a research regression model. When the equation model is fit, it can be carried out for the next test phase. Based on table 4 the results of the F test or anova, the calculated $\mathrm{F}$ value is 625,372 with a probability (significant) of 0,000 . Because the significance is much smaller than 0.05 , these results indicate that the regression equation model of the study is fit and feasible to be used to complete this research.

Table 4. F Test Results

\begin{tabular}{lccccc}
\hline Model & Sum of Squares & df & Mean Square & F & Sig. \\
\hline Regression & 120,271 & 9 & 13,363 & 625,372 &, $000^{\mathrm{b}}$ \\
Residual & 3,633 & 170 & 1 & \\
Total & 123,903 & 179 & & \\
\hline
\end{tabular}

a. Dependent Variable: DACC

b. Predictors: (Constant), CEO'S PICTURE, RECEIVABLE, COMPETENCE , CHANGE IN AUDITOR, ACHANGE, LEVERAGE, ROA, BDOUT, TATA

The output results in Table 6 show the value of Adjusted R Square is 0.969. These results mean that $96.9 \%$ of the DACC variation can be explained by variations of the nine independent variables financial targets, financial stability, external pressure, ineffective monitoring, nature of industry, change in auditor, rationalization, and competence. While the remaining $3.1 \%$ is explained by other factors not included in this research model.

Table 5. $t$ test results

\begin{tabular}{|c|c|c|c|c|c|}
\hline \multirow{2}{*}{ Model } & \multicolumn{2}{|c|}{ Unstandardized Coefficients } & \multirow{2}{*}{$\begin{array}{c}\begin{array}{c}\text { Standardized } \\
\text { Coefficients }\end{array} \\
\text { Beta }\end{array}$} & \multirow{2}{*}{$\mathbf{t}$} & \multirow{2}{*}{ Sig. } \\
\hline & B & Std. Error & & & \\
\hline (Constant) & ,137 & ,060 & & 2,277 & ,024 \\
\hline ROA & ,006 & ,023 & ,006 & ,277 & ,782 \\
\hline ACHANGE & 112 - & ,021 & ,097 & 5,391 & ,000 \\
\hline LEVERAGE & ,010 &, 004 & ,063 & 2,321 & ,021 \\
\hline BDOUT & ,018 & ,008 & ,061 & 2,307 & ,022 \\
\hline RECEIVABLE & ,050 & ,002 & ,832 & 25,103 & ,000 \\
\hline CHANGE IN AUDITOR & ,085 &, 057 & 023 & 1,484 & 140 \\
\hline TATA & ,120 & ,042 & 100 & 2,862 & 005 \\
\hline COMPETENCE & ,003 & ,023 & ,002 & 133 & 894 \\
\hline CEO'S PICTURE &,- 046 & ,030 &,- 020 & $-1,517$ & 131 \\
\hline
\end{tabular}

a. Dependent Variable: DACC

The first hypothesis of this research examines the effect of financial targets on the detection of fraudulent financial statements. Table 5 shows that the financial target variable has test results with a $t$ value of 0.277 with a significance level of 0.782 . The level of significance is greater than $\alpha=0.05$, which means that $\mathrm{H} 1$ is rejected. The results of this 
study are the same as research conducted by Sehrawat et al. (2019) which states that there is no significant influence between the independent variable on the financial target and the dependent variable on financial statement fraud. The second hypothesis of this research is to test the hypothesis about the effect of financial stability on the detection of financial statement fraud. Based on table 5, financial stability which is proxied by changes in total assets (ACHANGE) has a t test result which shows a $t$ value of 5.391 with a significance level of 0.000 . The level of significance is smaller than $\alpha=0.05$, which means that $\mathrm{H} 2$ is accepted. Thus, it can be concluded that partially financial stability has an effect on detecting fraudulent financial statements. This is because the ratio of changes in total assets has increased or decreased significantly, so that it is unstable and becomes a pressure on management. The results of this study are the same as research conducted by Hapsoro \& Husain (2019) which states that financial stability has a significant effect on fraudulent financial statements.

Table 6. $\mathbf{R}^{2}$ Test Results

\begin{tabular}{lcccc}
\hline Model & $\mathbf{R}$ & $\mathbf{R}$ Square & Adjusted R Square & Std. Error of the Estimate \\
\hline 1 &, $985^{\mathrm{a}}$ &, 971 &, 969 &, 1461804 \\
\hline a. Predictors: (Constant), CEO'S PICTURE, & RECEIVABLE, COMPETENCE, CHANGE IN AUDITOR, ACHANGE, \\
& LEVERAGE, ROA, BDOUT, TATA \\
b. Dependent Variable: DACC & & &
\end{tabular}

The third hypothesis of this research examines the effect of external pressure on the detection of fraudulent financial statements. Table 5 shows that the external pressure variable has a t test result with a value of 2.321 with a significance of 0.021 . The significance level is smaller than $\alpha=0.05$, which means that $\mathrm{H} 3$ is accepted, so it can be said that partially external pressure has an effect on the detection of fraudulent financial statements. The results of this study are in accordance with research conducted by Tessa (2016) which states that external pressure has a significant effect on fraudulent financial statements. The fourth hypothesis of this research is ineffective monitoring which is proxied by the ratio of the independent board of commissioners (BDOUT) which affects the detection of financial statement fraud. Table 5 shows that effective monitoring has a t test result with a value of 2.307 and a significance of 0.022 . The level of significance is smaller than $\alpha=0.05$, which means that $\mathrm{H} 4$ is accepted, so it can be said that partially ineffective monitoring has an effect on the detection of financial statement fraud. This is because the role of the board of commissioners is very important to control the company's operations, so that it can increase the effectiveness of supervising the company. The results of this study are different from research conducted by Tarigan et al. (2020) that states that ineffective monitoring does not have a significant effect on fraudulent financial statements.

The fifth hypothesis of this study is the nature of industry (RECEIVABLE) affects the detection of fraudulent financial statements. Table 4.5 illustrates that the $t$ test value for the nature of industry variable is 25.103 with a significance of 0.000 . The level of significance is smaller than $\alpha=0.05$, which means that H5 is accepted. The results of this study are the same as Sihombing (2014), which state that the nature of industry has a significant effect 
on fraudulent financial statements. The sixth hypothesis of this research is that change in auditors have an effect on the detection of financial statement fraud. Table 5 shows that the $t$ test results of the change in auditor variable are 1.484 with a significance of 0.140 . The level of significance is greater than $\alpha=0.05$, which means that $\mathrm{H} 6$ is rejected, so it can be said that partially the change in auditor variable has no effect on the detection of financial statement fraud. This is because the more frequent auditors change, the smaller it will be in detecting fraudulent financial statements. The results of this study support the research of Bawekes (2018) that state that change in auditors do not have a significant effect on fraudulent financial statements.

The seventh hypothesis is rationalization, which is proxied by TATA, which affects the detection of fraud in financial statements. Table 5 illustrates the $t$ test results for the rationalization variable with a $t$ value of 2.862 and a significance of 0.005 . The level of significance is smaller than $\alpha=0.05$, which means that $\mathrm{H} 7$ is accepted, so it can be said that partially the rationalization variable affects the detection of financial statement fraud. This is because there is an assumption that management uses total accruals to manage earnings. The results of this study are different from research conducted by Husmawati (2017) which states that rationalization does not have a significant effect on fraudulent financial statements.The eighth hypothesis of this study is that the change of directors has an effect on the detection of fraudulent financial statements. Table 5 shows that the $t$ value of the change of directors' variable (COMPETENCE) is 0.133 with a significance of 0.894. The level of significance is greater than $\alpha=0.05$, which means that H8 is rejected, so it can be said that partially the change of directors has no effect in detecting fraudulent financial statements. This shows that the change of directors is not a driving factor for fraud, because the more companies change directors, the less likely the company is to carry out earnings management.

The results of this study support the research conducted by Sihombing (2014), Jaya \& Ajeng (2019) which state that the change of directors has no significant effect on fraudulent financial statements. The ninth hypothesis of this study is that CEO's picture has an effect on the detection of financial statement fraud. Table 4.5 shows that the $t$ value of the CEO's picture variable is -1.517 with a significance of 0.131 . This significance level is greater than $\alpha=0.05$, which means that $\mathrm{H} 9$ is rejected, so it can be said that partially the CEO's picture has no effect in detecting fraudulent financial statements. The results of this study are different from the research of Tessa (2016); Jaya \& Poerwono (2019) who state that CEO's picture has a significant effect on fraudulent financial statements.

The results of this research indicate that during 2014-2019 there were still acts of fraudulent financial statements. This action occurs due to pressure from external pressure. This external pressure can be indicated as a result of various economic phenomena and economic crises that have had an impact and management is trying to show a good performance of financial reports to have a good impact on stakeholders or society. On the other hand, the pressure on banking companies cannot be separated from the role of the government in implementing normalization and refreshment policies for the debts of its customers in the hope that national economic conditions will return to normal. 


\section{CONCLUSION}

Based on the analysis and discussion of this research, it can be concluded that the variable financial targets, change in auditors, change of directors and CEO's picture have no effect on the detection of fraudulent financial statements. Meanwhile, financial stability, external pressure, ineffective monitoring, nature of industry, and rationalization have an effect on the detection of fraudulent financial statements for 2014-2019 from the sample companies of this study. The results of this study provide an understanding for the public and the general public that the government's efforts so far have always played a major role in maintaining the condition of the Indonesian economy in order to avoid attempts to commit fraudulent financial statements. Based on the results of this research, suggestions for future research include: Further researchers can conduct research on the same topic, but with comparative analytics during the period before and after the covid phenomenon 19 and researchers can then test an analysis of the policy on the impact of the spread of COVID-19 on the macro economy implemented by the government on current economic growth.

\section{REFERENCES}

Ahmed, A. S., \& Duellman, S. (2007). Accounting Conservatism and Board of Director Characteristics: An Empirical Analysis. Journal of Accounting and Economics, 43(2-3), 411-437. https://doi.org/10.1016/j.jacceco.2007.01.005

Bawekes, H., Simanjuntak, A., \& Daat, S. (2018). Pengujian Teori Fraud Pentagon Terhadap Fraudulent Financial Reporting. Jurnal Akuntansi Dan Keuangan Daerah, 13(1), 114-134.

Cahyani, A. M., Nuraina, E., \& Styaningrum, F. (2021). Fraudulent Financial Reporting on Property, Real Estate, and Building Construction Companies. Assets: Jurnal Akuntansi dan Pendidikan, 10(2), 132-147.

Chandra, D. P. N., Putu, W. A. A. G., Nyoman, B. I. G. A., \& Ketut, R. N. (2021). The Effect of Fraud Pentagon Theory on Financial Statements: Empirical Evidence from Indonesia. The Journal of Asian Finance, Economics and Business, 8(3), 1163-1169. https://doi. org/10.13106/JAFEB.2021.VOL8.NO3.1163.

Dewi, L. A. P., \& Kurniawan, P. S. (2017). Pengaruh Pemahaman Akuntansi Koperasi Berbasis Sak-Etap, Pemanfaatan Sistem Informasi Akuntansi, Dan Pengendalian Intern Akuntansi Terhadap Kualitas Laporan Keuangan (Studi Kasus Pada Koperasi Simpan Pinjam Di Kecamatan Buleleng). JIMAT (Jurnal Ilmiah Mahasiswa Akuntansi S1), 8(2). https://doi. org/10.23887/jimat.v8i2.14482

Hapsoro, D., \& Husain, Z. F. (2019). Does Sustainability Report Moderate The Effect of Financial Performance on Investor Reaction? Evidence of Indonesian Listed Firms. International Journal of Business, 24(3), 308-328.

Jaya, I. M. L. M., \& Narsa, I. M. (2020). The Beauty and the Beast of Earning Management in Indonesia. Opcion, 36(91), 1097-1140.

Jaya, I. M. L. M., \& Narsa, I. M. (2021). The Importance of Forensic Tax and Accounting Knowledge to Prevent Fraud in New Normal Era. Journal of Hunan University? Natural Sciences, 48(2), 101-112. 
Jaya, I. M. L. M., \& Poerwono, A. A. A. (2019). Pengujian Teori Fraud Pentagon Terhadap Kecurangan Laporan Keuangan Pada Perusahaan Pertambangan di Indonesia. Akuntabilitas: Jurnal Ilmu Akuntansi, 12(2), 157-168.

Manurung, D. T. H., \& Hardika, A. L. (2015). Analysis of Factors That Influence Financial Statement Fraud in The Perspective Fraud Diamond: Empirical Study on Banking Companies Listed on The Indonesia Stock Exchange year 2012 to 2014. Proceeding of International Conference on Accounting Studies (ICAS).

Mardianto, M., \& Tiono, C. (2019). Analisis Pengaruh Fraud Triangle Dalam Mendeteksi. Jurnal Benefita, 4, 87-103.

Omukaga, K. O. (2021). Is The Fraud Diamond Perspective Valid in Kenya? Journal of Financial Crime, 28(3), 810-840. https://doi.org/10.1108/JFC-11-2019-0141.

Ozcelik, H. (2020). An Analysis of Fraudulent Financial Reporting Using the Fraud Diamond Theory Perspective: An Empirical Study on the Manufacturing Sector Companies Listed on the Borsa Istanbul. In S. Grima, E. Boztepe, \& P. J. Baldacchino (Eds.), Contemporary Issues in Audit Management and Forensic Accounting (Vol. 102, pp. 131-153). Emerald Publishing Limited. https://doi.org/10.1108/S1569-375920200000102012.

Rexhepi, G., Ibraimi, S., \& Veseli, N. (2013). Role of Intellectual Capital in Creating Enterprise Strategy. Procedia -Social and Behavioral Sciences, 75, 44-51. https://doi.org/10.1016/j. sbspro.2013.04.006

Sarikhani, M., \& Ebrahimi, F. (2021). Whistleblowing by Accountants: An Integration of The Fraud Pentagon and The Extended Theory of Planned Behavior. Meditari Accountancy Research, In-press. https://doi.org/10.1108/MEDAR-10-2020-1047

Sehrawat, N. K., Kumar, A., Lohia, N., Bansal, S., \& Agarwal, T. (2019). Impact of Corporate Governance on Earnings Management: Large Sample Evidence from India. Asian Economic and Financial Review, 9(12), 1335-1345. https://doi.org/10.18488/journal. aefr.2019.912.1335.1345

Skousen, C. J., Smith, K. R., \& Wright, C. J. (2009). Detecting and predicting financial statement fraud: The effectiveness of the fraud triangle and SAS No. 99. In M. Hirschey, K. John, \& A. K. Makhija (Eds.), Corporate Governance and Firm Performance (Vol. 13, pp. 53-81). Emerald Group Publishing Limited. https://doi.org/10.1108/S15693732(2009)0000013005

Sumiati, S. (2020). Improving Small Business Performance: The Role of Entrepreneurial Intensity and Innovation. The Journal of Asian Finance, Economics and Business, 7(10), 211-218. https://doi.org/10.13106/jafeb.2020.vol7.n10.211

Tarigan, Z. J. H., Siagian, H., \& Jie, F. (2020). The Role of Top Management Commitment to Enhancing The Competitive Advantage Through ERP Integration and Purchasing Strategy. International Journal of Enterprise Information Systems, 16(1), 53-68. https:// doi.org/10.4018/IJEIS.2020010103

Vrontis, D., Christofi, M., Battisti, E., \& Graziano, E. A. (2020). Intellectual Capital, Knowledge Sharing and Equity Crowdfunding. Journal of Intellectual Capital, 22(1), 95-121. https:// doi.org/10.1108/JIC-11-2019-0258 
Yuliani, S. (2010). Pengaruh Pemahaman Akuntansi, Pemanfaatan Sistem Informasi Akuntansi Keuangan Daerah Dan Peran Internal Audit Terhadap Kualitas Laporan Keungan Pemerintah Daerah (Studi Empiris Pada Pemerintah Kota Banda Aceh). Jurnal Telaah Dan Riset Akuntansi, 3(2), 206-220. 